\title{
The Effects of Distance Education Applied Due to COVID-19 on Clinical Neurology Education
}

\author{
COVID-19 Nedeniyle Uygulanan Uzaktan Ë̆itimin Nöroloji Klinik Ĕ̈itimine Etkileri
}

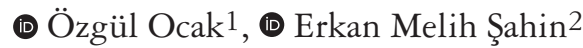 \\ ${ }^{1}$ Canakkale Onsekiz Mart University Faculty of Medicine, Department of Neurology, Canakkale, Turkey \\ ${ }^{2}$ Canakkale Onsekiz Mart University Faculty of Medicine, Department of Family Medicine, Canakkale, Turkey
}

\begin{abstract}
Objective: The aim of this study was to compare distance and face-to-face learning models applied in neurology clinic education during the coronavirus disease-2019 (COVID-19) pandemic.

Materials and Methods: Medical faculty students who received clinical neurology education in the 2019-2020 academic years were included in the study. The online questionnaire used in the study consisted of three parts. The first part contained questions on students' sociodemographic data and education; in the second part, questions were asked on the students' competence level in meeting the cognitive and practical learning objectives of clinical neurology education; and in the third part, the medical school students' attitudes toward online learning scale was included.

Results: The average passing grades of the 45 students (84.3) who took the clinical neurology education face to face were lower than those of the 40 participants (91.1) who received distance education. In 30 of the 40 cognitive goals and 39 of the 40 practical goals, the group averages of the students who received face-toface training were higher than those of the distance education group. There was no correlation between passing grades and total scores on cognitive and practical goals. There was a significant correlation between the cognitive and practical total scores of the students and attitude scale toward distance/online learning scale score in the distance education group.

Conclusion: Distance education was started for clinical neurology education in the COVID-19 pandemic. The proficiency levels declared by students regarding their learning goals after distance education were lower. The results achieved with distance education, especially in practical goals, were worse. Conversely, student grades were higher in the distance education group. These results show that there are serious difficulties in measurement and evaluation methods in distance education. It is necessary to review the experiences gained from the pandemic to eliminate deficiencies and improve clinical neurology education.
\end{abstract}

Keywords: COVID-19, distance education, clinical neurology education

Öz

Amaç: Bu araştırmada, koronavirüs hastalı̆̆1-2019 (COVID-19) pandemisi sürecinde nöroloji klinik eğitiminde uygulanan uzaktan eğitimin yüz yüze eğitim ile karşılaştırılması amaçlanmıştır.

Gereç ve Yöntem: Çalışmaya 2019-2020 eğitim döneminde nöroloji klinik eğitimi alan tıp fakültesi öğrencileri dahil edildi. Araştırmada kullanılan online anket formu üç bölümden oluşmaktadır. İlk bölümde öğrencilerin sosyo-demografik özellikleri ve eğitimleriyle ilgili bilgileri, ikinci bölümde öğrencilerin nöroloji klinik eğitimi bilişsel ve uygulama öğrenim hedeflerine yönelik yeterlilik soruları, üçüncü bölümde tıp fakültesi öğrencilerinin uzaktan eğitim/online öğrenmeye yönelik tutum ölçeği yer almı̧sır.

Bulgular: Nöroloji klinik eğitimini yüz yüze alan 45 öğrencinin ortalama geçme notları $(84,3)$ eğitimi uzaktan eğitim yöntemleriyle alan 40 öğrencinin notundan $(91,1)$ düşüktü. İncelenen 40 bilişsel hedeften 30'unda ve 40 uygulama hedefinden 39'unda yüz yüze eğitim alan grup ortalamaları uzaktan eğitim alan grup ortalamalarından daha yüksekti. Geçme notları ile bilişsel ve uygulama hedefleri toplam puanları arasında korelasyon yoktu. Uzaktan e ğitim alan öğrencilerin toplam bilişsel ve toplam uygulama hedef puanları ile uzaktan/online öğrenmeye yönelik tutum ölç̧ği puanı arasında anlamlı korelasyon mevcuttu.

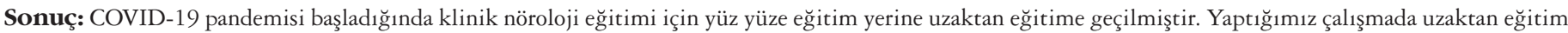
sonrası öğrencilerin öğrenim hedefleri ile ilgili yeterlilik bildirimleri daha düşük bulunmuştur. Uzaktan eğitim ile özellikle uygulama hedeflerinde elde edilen

Address for Correspondence/Yazışma Adresi: Özgül Ocak MD, Canakkale Onsekiz Mart University Faculty of Medicine, Department of Neurology, Canakkale, Turkey

E-mail: dr_ozgul@hotmail.com ORCID: orcid.org/0000-0001-8276-0174

Received/Geliș Tarihi: 23.01.2021 Accepted/Kabul Tarihi: 10.06.2021

${ }^{\circ}$ Copyright 2021 by Turkish Neurological Society

Turkish Journal of Neurology published by Galenos Publishing House. 


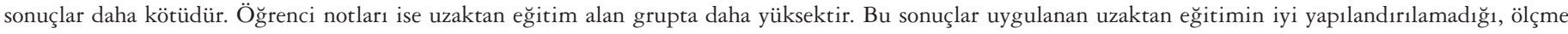

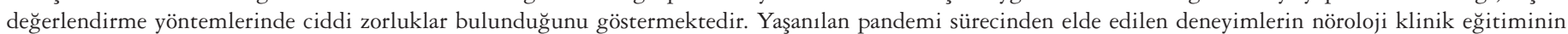
iyileştirilmesi amacıyla gözden geçirilmesi ve eksikliklerin giderilmesi gereklidir.

Anahtar Kelimeler: COVID-19, uzaktan eğitim, nöroloji klinik eğitimi

\section{Introduction}

The novel coronavirus disease-2019 (COVID-19) pandemic has affected the whole world in economic, sociocultural, health, education, and many other aspects. Unlike previous epidemic disease outbreaks, it is not limited to regions or continents but has spread all over the world (1). Although the COVID-19 pandemic has caused problems in education, it has also allowed education systems to be reviewed and provided an opportunity to update methods that have lost their validity (2). With the closure of educational institutions and the suspension of faceto-face education, the education of approximately 1.6 billion students from different education levels has been interrupted all over the world. In Turkey, the number of students affected by the interruption of education has reached approximately 25 million (3).

Although rapid studies are carried out in the field of health in order to understand COVID-19 and produce a solution to the pandemic, studies in the field of education is insufficient (4). In order to compensate for the interruption of education due to the pandemic, emergency distance education applications have been initiated rapidly all over the world. This has initiated comparisons between face-to-face education and distance education. Medical school education, unlike other disciplines, is a more complex situation as it concerns two fields: Health and education.

Medical school students have difficulties in identifying and managing patients with neurological problems. Students stated that they had limited information about patients with neurological complaints and that they lacked confidence in this regard (5). In the United Kingdom and Ireland, students and junior doctors rated neurology as the most difficult of all medical specialties $(6,7)$.

We aimed to evaluate whether students who received clinical neurology training at the Faculty of Medicine of Canakkale Onsekiz Mart University in 2019-2020, who completed their education by distance education and students who received face-toface education experienced educational inequality and inadequacy. Additionally, we aimed to investigate the applicability of distance education in medical faculties.

\section{Materials and Methods}

The data collection phase of this cross-sectional study was carried out with a structured questionnaire applied on the internet between December 15, 2020 and January 15, 2021.

Before the start of the study, approval was obtained from the Clinical Research Ethics Committee of the University of Canakkale Onsekiz Mart University (decision no: 2020-14, date: 09.12.2020) and the Dean of the Faculty of Medicine. Medical faculty students who received clinical neurology training through face-to-face or distance education in the 2019-2020 academic years and volunteered to participate in the study were included in the study.

The questionnaire form prepared using the "Microsoft Forms" application was sent via link sharing to individuals who volunteered to participate in the study. The questionnaire form used in the research consists of three parts. The first part asks questions about students' sociodemographic information, including their age and gender, number of years in medical school, the education method (face-to-face or distance education) they received during their clinical neurology education, and their passing grades. In the second part, there are questions concerning how adequate the students feel about the learning objectives of the clinical neurology education. In the third part, there is the Attitudes Toward Distance Education/Online Learning Scale of Medical Faculty Students (TUEYT), which determines the attitudes of the students toward distance education.

In order to determine how satisfied the students felt about their learning goals, 40 practical learning goals were selected that made up the application learning goals of clinical neurology education, and 40 cognitive learning goals were selected in a balanced manner among the cognitive learning goals to represent the learning goals of cognitive clinical neurology education Canakkale Onsekiz Mart University Faculty of Medicine education program is a nationally accredited education program. (8) In this respect, the selected learning objectives consist of the learning objectives of an education segment of an accredited medical education program. Participants were asked to indicate how competent they felt for each learning goal, using the numerical ratio scale (1; I think I have not learned at all and 10; I think I have learned completely). Cognitive goal total score is calculated by summing the responses of 40 cognitive goals, and the total score of practical goals is calculated by summing the responses of 40 practical goals.

The attitude scale of medical faculty students TUEYT is a validated scale created to determine the attitudes of medical faculty students toward distance education. Scale responses from 22 questions are collected on a 5-point Likert scale (1: Strongly disagree, 2: Disagree, 3: Partially agree, 4: Agree, 5: Strongly agree) with response matches. The scale score obtained by adding the response scores obtained for each question can vary between 22 and 110 points. There is no reported cutoff value. As the total score increases, the attitude toward distance education changes in the positive direction.

\section{Statistical Analysis}

After the study data were digitized and arranged, frequencies and percentages were calculated for categorical variables, and mean and standard deviation for continuous variables. Analyses were performed with chi-square, Student's t-test, paired- samples t-test, and Pearson's correlation tests in accordance with the data characteristics. Since the number of samples was larger than 30 , the assumption of the normal distribution was neglected in parametric tests based on the central limit theorem. The cut-off level of significance was accepted as $\mathrm{p}<0.05$ for all analyses, and the test constant and absolute $\mathrm{p}$ values were given for each analysis. 


\section{Results}

The online questionnaire prepared for the study was filled out by 88 participants, and the results of 85 participants were analyzed, excluding three of whom had a significant lack of data.

Of the 85 participants, there were $45(52.9 \%)$ participants who received face-to-face education and 40 (47.1\%) participants who were educated by distance learning. Forty-eight $(56.5 \%)$ of the participants were female and $37(43.5 \%)$ were male, and their mean age was $24.0 \pm 1.1$ (minimum 23 , maximum 28 ). There was no significant difference in terms of gender and age between those who received their education face to face and those who received distance education (Table 1 ). The starting year of medical school was 2016 in one (1.2\%) student, 2015 in 71 (83.5\%) students, 2014 in $8(9.4 \%)$ students, 2013 in $3(3.5 \%)$ students, and 2011 or earlier in $2(2.4 \%)$ students. The proportion of students who lost years in medical school was not significantly different between the two education method groups (Table 1).

The mean passing grade of the students who had clinical neurology education in the previous year was $87.67 \pm 7.53$ (minimum 65-maximum 100). The mean passing grade $(84.29 \pm 7.65)$ of the students who received face-to-face education was significantly lower than that $(91.13 \pm 5.66)$ of students who received distance education $(\mathrm{t}=4.578, \mathrm{p}<0.001)$ (Figure 1$)$.

The total cognitive goals score $(272.95 \pm 73.39)$ for all participants was significantly higher than the practical goals total score $(261.79 \pm 71.33)(t=2.501, p=0.014)$. Among the cognitive goals, the learning goal with the highest proficiency score $(8.25 \pm 2.14)$ was "Explains the Glasgow-Coma scale", and the learning goal with the lowest proficiency score $(4.74 \pm 2.75)$ was "Explains the diagnosis and treatment of CIDP". Among the practical goals, the learning goal with the highest proficiency score was $(7.77 \pm 2.26)$ "Explains informed consent to patients and witnesses", and the learning goal with the lowest proficiency score $(4.75 \pm 2.51)$ was "Counts the methods of examining LP samples".

There was no significant difference between the cognitive goals total score and the practical goals total score in terms of gender $(t=0.559, p=0.578$ and $t=0.166, p=0.868$, respectively). There was no significant difference between those with and without loss of years in terms of cognitive goals total scores and practical goals total scores $(t=0.809, p=0.421$ and $t=0.586, p=0.559$, respectively). There was no correlation between the ages of the participants and the total scores of cognitive and practice goals $(\mathrm{r}=-0.107, \mathrm{p}=0.336$ and $\mathrm{r}=-0.204, \mathrm{p}=0.066$, respectively). There was no correlation between the participants' passing grades and the total scores of cognitive and practical goals $(r=-0.078, p=0.493$, and $\mathrm{r}=-0.086, \mathrm{p}=0.451$, respectively).

There was a significant high correlation between the participants' total scores of cognitive goals and total scores of practical goals $(\mathrm{r}=0.848, \mathrm{p}<0.001)$.

The total mean scores of cognitive and practical learning goals of the participants who received clinical neurology education through the face-to-face method and those of participants who received distance education are presented in Table 2 . The mean scores of 30 of the 40 cognitive goals examined were higher in the group that received face-to-face education, and the mean scores of 10 of the 40 cognitive goals examined were higher in the group that received distance education. In terms of the goals of "Takes anamnesis for the diagnosis of neurological diseases" and "Describes the examination of the cerebellar system", the mean of the group that received face-to-face education was significantly higher than the mean of the group that received distance education $(\mathrm{t}=2.179, \mathrm{p}=0.032, \mathrm{t}=2.340, \mathrm{p}=0.022$, respectively). The mean of the group that received face-to-face education was higher in 39 of the 40 practical goals examined, and the mean of the group that received distance education in one of them. The mean of the group that received face-to-face education was significantly higher

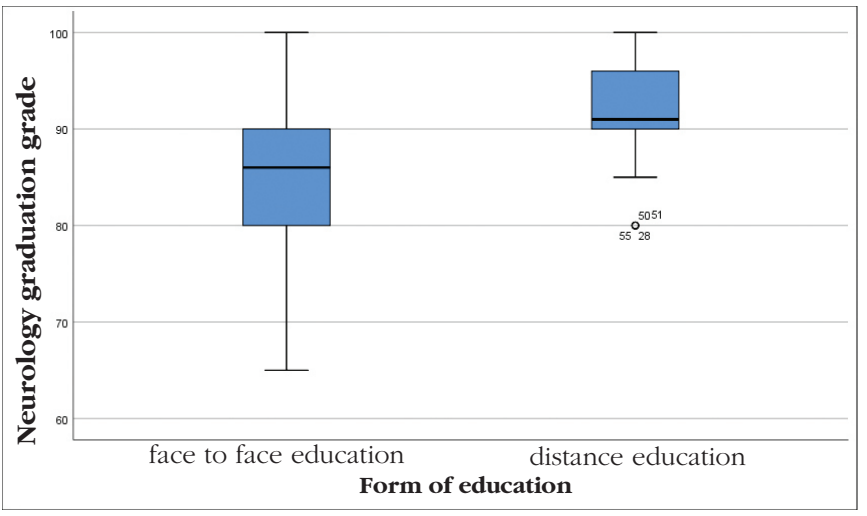

Figure 1. Distribution of passing grades by education method Table 1. Demographic and academic characteristics of the participants according to the education method

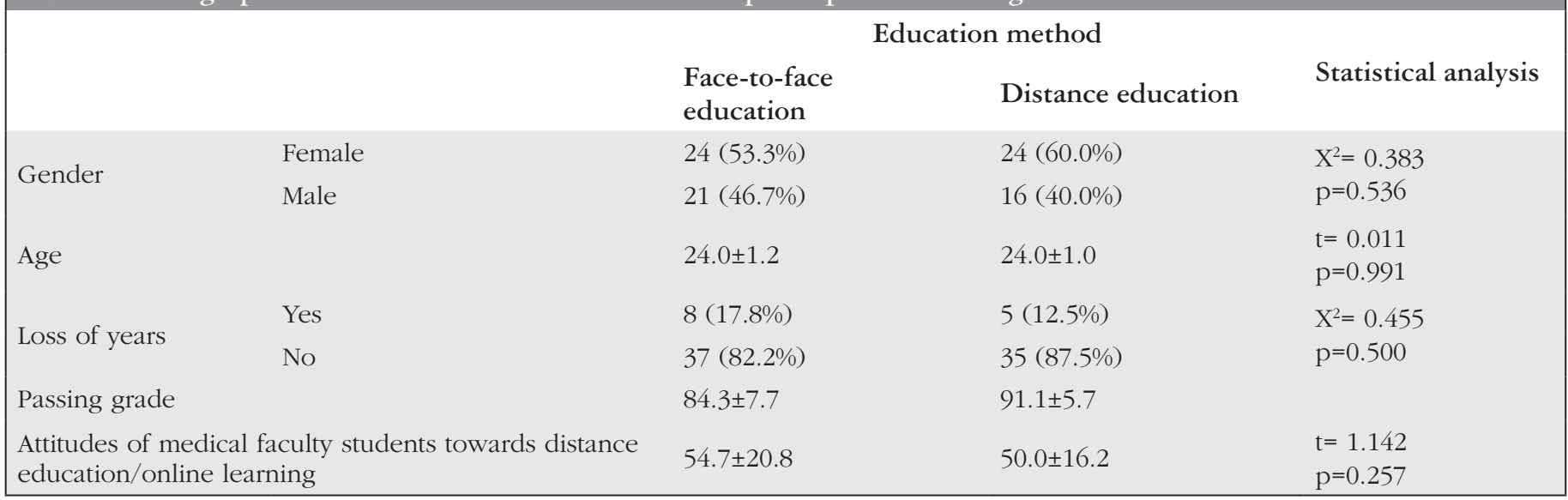


Table 2. The mean scores of the participants regarding their achievement of cognitive and practical learning goals according to the education method

\begin{tabular}{|c|c|c|c|}
\hline & $\begin{array}{l}\text { Face-to-face } \\
\text { education }\end{array}$ & $\begin{array}{l}\text { Distance } \\
\text { education }\end{array}$ & Total \\
\hline \multicolumn{4}{|l|}{ Cognitive goals } \\
\hline Understands the anatomy and physiology of the nervous system & $6.0 \pm 2.6$ & $6.2 \pm 2.2$ & $6.1 \pm 2.4$ \\
\hline $\begin{array}{l}\text { Recognizes the symptoms seen in neurological diseases and counts the appropriate } \\
\text { principles of approach to patient }\end{array}$ & $7.2 \pm 2.0$ & $6.3 \pm 2.2$ & $6.8 \pm 2.1$ \\
\hline Takes anamnesis for the diagnosis of neurological diseases & $8.0 \pm 2.2$ & $7.0 \pm 2.2$ & $7.5 \pm 2.2$ \\
\hline Describes speech disorders & $7.0 \pm 2.7$ & $6.2 \pm 2.4$ & $6.6 \pm 2.6$ \\
\hline Describes cranial nerve examination & $7.9 \pm 2.2$ & $7.4 \pm 2.5$ & $7.7 \pm 2.3$ \\
\hline Describes motor system examination & $7.6 \pm 2.1$ & $7.1 \pm 2.3$ & $7.4 \pm 2.2$ \\
\hline Describes sensory system examination & $7.2 \pm 2.2$ & $7.0 \pm 2.5$ & $7.1 \pm 2.4$ \\
\hline Describes cerebellar system examination & $7.7 \pm 2.3$ & $6.5 \pm 2.4$ & $7.1 \pm 2.4$ \\
\hline Describes deep tendon reflex examination & $7.8 \pm 2.2$ & $7.5 \pm 2.2$ & $7.7 \pm 2.2$ \\
\hline Counts pathological reflexes & $7.6 \pm 2.1$ & $7.8 \pm 2.2$ & $7.7 \pm 2.1$ \\
\hline Counts the usage areas of lumbar puncture in diagnosis & $7.0 \pm 2.0$ & $6.4 \pm 2.0$ & $6.7 \pm 2.0$ \\
\hline $\begin{array}{l}\text { Lists the diagnostic uses of electroencephalography, electromyography, } \\
\text { polysomnography and neuroradiological tests }\end{array}$ & $6.4 \pm 2.4$ & $5.9 \pm 2.6$ & $6.2 \pm 2.5$ \\
\hline Explains the principles of approach to neurological emergency patients & $7.2 \pm 2.2$ & $6.4 \pm 2.5$ & $6.9 \pm 2.4$ \\
\hline $\begin{array}{l}\text { Lists the distinguishing features of primary and secondary headaches in emergency } \\
\text { admission. }\end{array}$ & $7.5 \pm 2.1$ & $7.2 \pm 2.3$ & $7.4 \pm 2.2$ \\
\hline $\begin{array}{l}\text { Lists the principles of first approach to patient with unconsciousness in emergency } \\
\text { admission }\end{array}$ & $7.2 \pm 2.3$ & $6.7 \pm 2.4$ & $6.9 \pm 2.4$ \\
\hline Explain the Glasgow-Coma scale & $8.5 \pm 2.2$ & $8.0 \pm 2.1$ & $8.3 \pm 2.1$ \\
\hline Counts neurological emergencies that cause movement disorders & $7.2 \pm 2.1$ & $6.8 \pm 2.0$ & $7.0 \pm 2.0$ \\
\hline Explain emergencies of neuromuscular junction diseases & $6.4 \pm 2.3$ & $6.3 \pm 2.5$ & $6.3 \pm 2.4$ \\
\hline $\begin{array}{l}\text { Explains the emergency intervention and treatment of the patient who is admitted to } \\
\text { the emergency department with epileptic seizure }\end{array}$ & $7.3 \pm 2.4$ & $7.4 \pm 2.2$ & $7.3 \pm 2.3$ \\
\hline Comprehends the importance of preventive medicine in neurological diseases & $7.3 \pm 2.3$ & $7.2 \pm 2.5$ & $7.2 \pm 2.4$ \\
\hline Makes an appropriate treatment plan for tension-type headache & $6.9 \pm 2.4$ & $6.7 \pm 2.2$ & $6.8 \pm 2.3$ \\
\hline $\begin{array}{l}\text { Lists neurological treatment agents, indications, contraindications and application } \\
\text { methods }\end{array}$ & $6.2 \pm 2.3$ & $6.0 \pm 2.7$ & $6.1 \pm 2.5$ \\
\hline Counts the tests that should be requested in the emergency patient with stroke & $7.5 \pm 2.4$ & $7.0 \pm 2.4$ & $7.3 \pm 2.4$ \\
\hline Explain the risk factors in patients with ischemic stroke & $7.6 \pm 2.3$ & $6.8 \pm 2.5$ & $7.2 \pm 2.4$ \\
\hline Counts which patients will be given acute ischemic stroke treatment & $7.0 \pm 2.5$ & $6.8 \pm 2.5$ & $6.9 \pm 2.5$ \\
\hline Lists the principles to be considered in the treatment and follow-up of ischemic stroke & $6.8 \pm 2.4$ & $6.6 \pm 2.6$ & $6.7 \pm 2.5$ \\
\hline $\begin{array}{l}\text { Explains the clinical pictures that may occur according to the localization of } \\
\text { hemorrhagic stroke }\end{array}$ & $6.6 \pm 2.5$ & $6.6 \pm 2.4$ & $6.6 \pm 2.4$ \\
\hline Explain the etiology of demyelinating diseases & $6.2 \pm 2.1$ & $6.3 \pm 2.5$ & $6.3 \pm 2.3$ \\
\hline Counts the clinical findings of demyelinating diseases & $6.8 \pm 2.2$ & $6.4 \pm 2.3$ & $6.6 \pm 2.3$ \\
\hline Counts pathologies that may increase intracranial pressure & $7.4 \pm 2.3$ & $7.1 \pm 2.3$ & $7.3 \pm 2.3$ \\
\hline Explains the neurological examination findings of increased intracranial pressure & $7.9 \pm 2.2$ & $7.6 \pm 2.0$ & $7.8 \pm 2.1$ \\
\hline Explains the anatomy of the peripheral nervous system & $6.0 \pm 2.8$ & $6.2 \pm 2.5$ & $6.1 \pm 2.7$ \\
\hline Explains the definition and causes of polyneuropathy & $6.4 \pm 2.3$ & $6.9 \pm 2.3$ & $6.7 \pm 2.3$ \\
\hline Explains the medical treatments of entrapment neuropathies & $7.2 \pm 2.6$ & $7.6 \pm 2.3$ & $7.4 \pm 2.5$ \\
\hline Explains the differential diagnosis of peripheral nervous system diseases & $6.5 \pm 2.4$ & $6.4 \pm 2.2$ & $6.5 \pm 2.3$ \\
\hline Explains the diagnosis and treatment of GBS & $6.1 \pm 2.3$ & $6.1 \pm 2.1$ & $6.1 \pm 2.2$ \\
\hline Explains the diagnosis and treatment of chronic inflammatory demyelinating disease & $4.4 \pm 2.7$ & $5.1 \pm 2.8$ & $4.7 \pm 2.8$ \\
\hline Counts the clinical findings of neuromuscular junction diseases & $6.3 \pm 2.5$ & $6.1 \pm 2.2$ & $6.2 \pm 2.4$ \\
\hline Explains the differential diagnosis of neuromuscular junction diseases & $6.2 \pm 2.3$ & $6.0 \pm 2.3$ & $6.1 \pm 2.3$ \\
\hline Tells the features of Myasthenia Gravis Disease & $7.4 \pm 2.20$ & $7.6 \pm 2.0$ & $7.5 \pm 2.1$ \\
\hline Total & $277.9 \pm 75.6$ & $268.6 \pm 73.7$ & $273.4 \pm 73.9$ \\
\hline
\end{tabular}


Table 2. continued

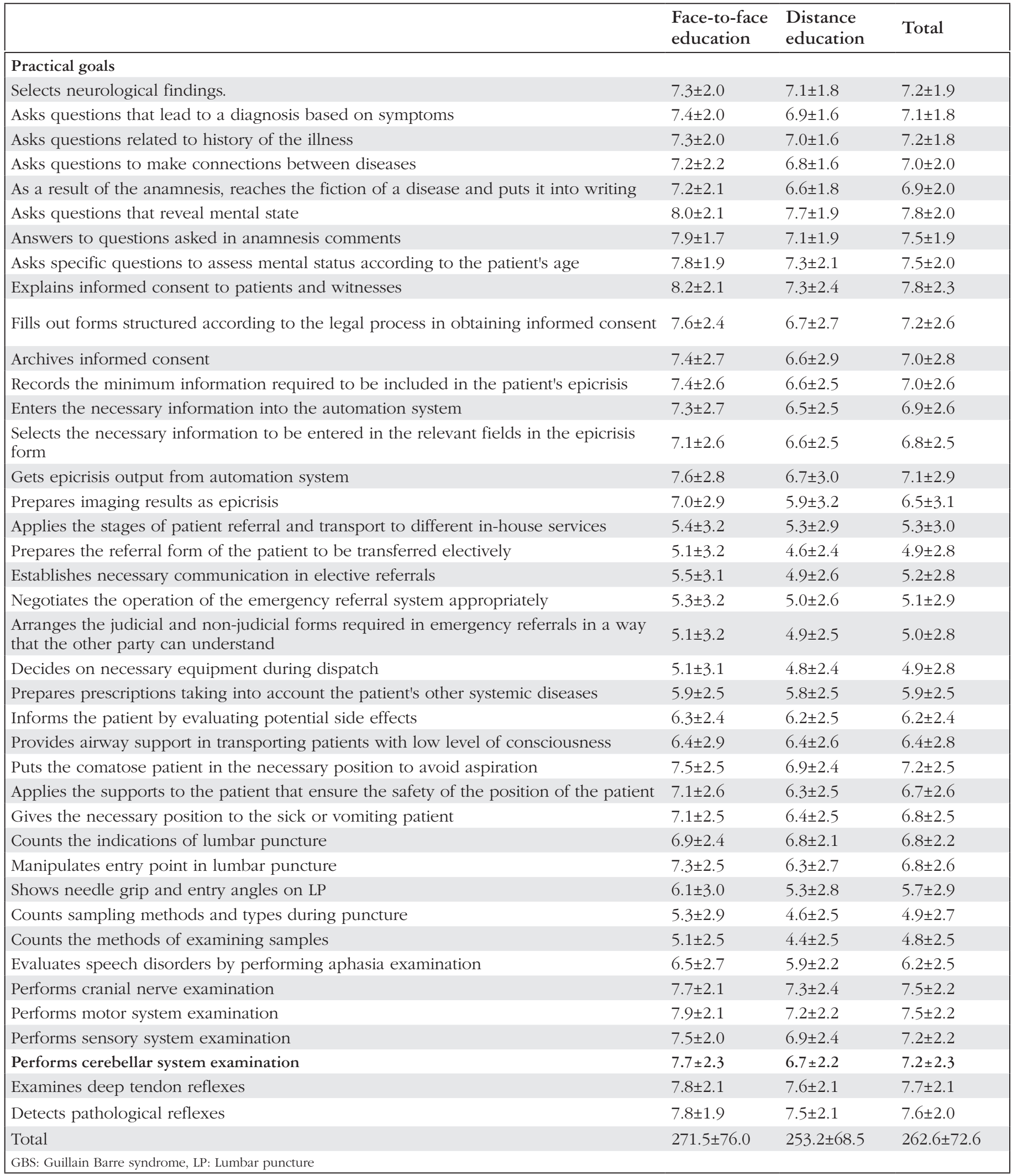


than that of the group that received distance education in terms of the goal "Describes cerebellar system examination" $(\mathrm{t}=2.071$, $\mathrm{p}=0.042$ ). The mean cognitive goals total scores (Figure 2) and practical goals total scores (Figure 3 ) of the two groups were not significantly different $(\mathrm{t}=0.576, \mathrm{p}=0.566 ; \mathrm{t}=1.145, \mathrm{p}=0.256$, respectively).

There was no correlation between the passing grades of the face-to-face trainees and the total scores for cognitive and practical goals $(\mathrm{r}=-0.059, \mathrm{p}=0.722$ and $\mathrm{r}=-0.049, \mathrm{p}=0.768$, respectively). There was no correlation between the passing grades of those who received distance education and the total scores for cognitive and practical goals $(\mathrm{r}=0.000, \mathrm{p}=1.000$ and $\mathrm{r}=0.022, \mathrm{p}=0.893$, respectively).

The mean score of the participants' TUEYT scale was $52.40 \pm 18.68$ (minimum 22, maximum 109). Scale scores were not significantly different between those who received faceto-face education and those who received distance education $(t=1.142, p=0.257)$. Scale scores were not significantly different

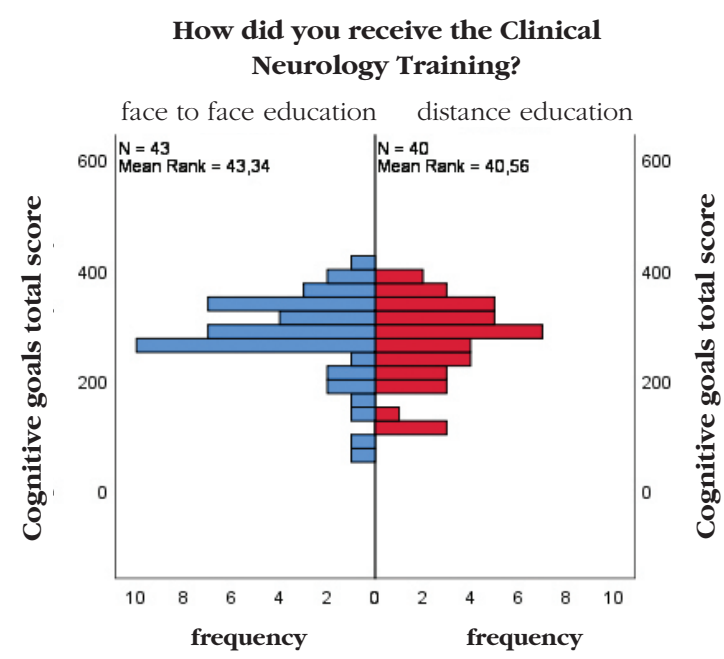

Figure 2. Cognitive goals total score distribution by training method

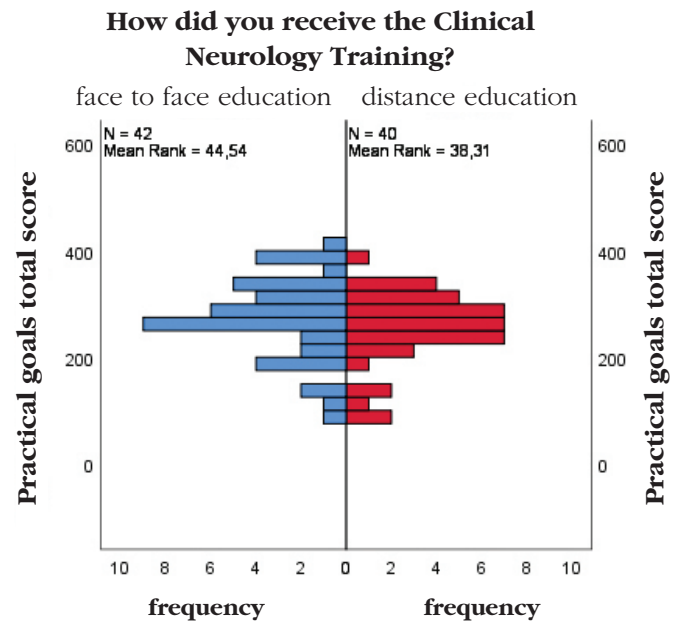

Figure 3. Practical goals total score distribution according to the education method between genders $(t=0.499, p=0.619)$. Scale scores were not significantly different between those with and without lost years $(\mathrm{t}=0.320, \mathrm{p}=0.750)$. There was no correlation between age and scale score $(\mathrm{r}=0.093, \mathrm{p}=0.409)$. When all participants were evaluated together, there was no significant correlation between passing grades and scale scores $(\mathrm{r}=-0.056, \mathrm{p}=0.622)$. There was no significant correlation between the passing grades and scale scores of the students who received their education through the face-toface method and those who received distance education $(r=-0.030$, $\mathrm{p}=0.858, \mathrm{r}=0.062, \mathrm{p}=0.706$, respectively).

There was no correlation between total cognitive and total practical goal scores and scale scores $(r=0.115, p=0.311, r=0.204$, $\mathrm{p}=0.071$, respectively). There was no correlation between the total cognitive and total practical goal scores and the scale scores of the students who received face-to-face education $(r=-0.063$, $\mathrm{p}=0.698, \mathrm{r}=0.035, \mathrm{p}=0.833$, respectively). There was a significant correlation between the total cognitive and total practical goal scores and the scale scores of the distance education students $(\mathrm{r}=0.337, \mathrm{p}=0.034, \mathrm{r}=0.421, \mathrm{p}=0.007$, respectively).

\section{Discussion}

The COVID-19 pandemic, which is projected to continue for a long time, affects 1.6 billion students worldwide (9). As observed in the experiences of previous pandemics, the same reactions were given to the interruption of education, and technologyoriented solutions were produced in education. With the onset of the pandemic, emergency distance education started, and temporary solutions were produced to meet the needs of students and educators (10). The COVID-19 pandemic has shown us that education systems all over the world and in Turkey are unprepared to ensure the continuity of education under all circumstances (2). During the COVID-19 process, medical faculties in Turkey did not accept to shorten the education period and hold graduation early, and some faculties demanded that student graduation be delayed (11).

During the pandemic process, which affected the whole world, significant changes were made in the 2019-2020 academic year to cover the spring semester. After our hospital was declared a pandemic hospital, pandemic services, pandemic tents, and pandemic intensive care units were opened in line with the instructions of the Presidency, Ministry of Health Science Board, and Higher Education Institution. Research assistants and faculty members also started to be assigned to these units. Medical educators, who were also health workers, had to give priority to preventing the pandemic and giving patient care. Distance education methods were implemented for educational activities in order to prevent disease contact and transmission among students.

In our study, comparisons were made between the students who received their clinical neurology training through the face-toface education method and those who received distance education in terms of passing grades and proficiency levels in achieving learning goals, and the effect of attitudes toward distance education on those was examined. As the pandemic progressed, the clinical neurology learning goals and proficiency statements of the students were found to be lower after distance education, which was used as an alternative solution due to the suspension of face-to-face education. It was noteworthy that students who received face-toface education reported higher proficiency for most learning goals, although those who achieved significance on the basis of learning 
goals remained limited. Almost all practical goals had this feature. However, those who received distance education received higher passing grades. These results show that distance education is not well structured, and there are serious difficulties in measurement and evaluation methods. In the current situation, it may seem reasonable that the transition to a distance education method is due to urgency. However, improvements should be made quickly in this regard, and careful attention should be paid to the distance education activities to be continued after pandemic restrictions are lifted.

Students' attitudes toward distance education vary. In our study, there was a significant correlation between the total cognitive and practical goal scores and the TUEYT scale score of the students who received their clinical neurology education via distance education. This shows that good results can be obtained with distance education when the appropriate choices are made according to student characteristics.

While there are temporary solutions for the current need with emergency distance education, permanent solutions can be reached for some of the limitations in the education system with the established implementation of distance education (12). While it is certain that face-to-face education is more valuable for students, it has been determined that web-based distance education supports critical thinking and high-level learning (13). Some students found distance education exciting, while others reported it to be disadvantageous (14). No difference was found in terms of satisfaction of nursing students between web-based distance education and face-to-face education (15). Dentistry students showed that distance education encouraged independent learning and improved their skills in using online resources (16). Pharmacy faculty students reported that face-to-face and distance education together were more effective (17). Medical faculty students reported that courses conducted with direct and open communication with their classmates and educators increased trust and cooperation (18).

Patient examination, which is an important part of medical school education, is only possible with close contact. With distance education, there may be deficiencies in the practical training of students. In addition, medical faculty students should be able to work as a team in a crisis, cooperate at a high level and support each other (19).

With the transition of medical school students to distance education, there have been problems in practical training in many clinics. With the start of distance education, many practice courses could not be held in the neurology clinic, as in other clinics, and throughout the process, attempts were made to explain the approach to neurological diseases explained in distance education instead of practical education. Applications made to save the day in the short term will face us with deficiencies in medical education and greater negativities in the long run. For this reason, it is important to prevent negative experiences of students and educators who experience distance education for the first time (20).

Although students have face-to-face education and practical courses, distance education in neurology, which poses difficulties in diagnosis and differential diagnosis, may have limited the students' experience with neurology patients, and difficulties in approaching patients may have started. The number of studies conducted thus far to evaluate this aspect is very few and insufficient. We believe that the findings of our study will be a guide for both students and educators.

Since there is no precedent for the current problem affecting non-formal education on a global scale to this extent, there are no ready-made solutions. Experiences of the closure of local schools due to various disasters do not produce a proposed solution for the current situation (21). Regardless of the educational method in medical education, assessments should continue to be valid, reliable, and applicable. It is necessary to redesign the standard assessment methods used when distance education is applied. While some of the arrangements to be made remain temporary under pandemic conditions, others may become a permanent part of the evaluation system. Thus, the COVID-19 pandemic can be used as an opportunity to improve the design, planning, and implementation of assessment systems (21). Most medical faculties use face-to-face evaluation methods, especially to ensure the integrity and safety of the examination. It is not appropriate to use these evaluation methods in the usual way in pandemic conditions, and evaluation processes need to be strengthened (22). In addition to adhering to the principles of validity, reliability, and fairness in evaluation, multiple measurements should be made, and formative and summative tasks should be included (23). In addition, issues of accessibility, legality, identity, security, and academic integrity should be considered in remote assessment activities (24). One of the main challenges of remote evaluation is the combined issue of copying, plagiarism, and cheating. Although these problems are also present in the traditional learning environment, the online environment, with its many features, increases the opportunity for and attraction of dishonest behavior (25). Given the validity, reliability, safety, and confidentiality of remote assessment, as well as the difficulty of assessing group interaction and technical difficulties, oral assessments can be an attractive option (24).

It is normal to make comparisons between distance education and face-to-face education, as this is the most serious change observed in education during the pandemic. According to the meta-analysis conducted by Russell (26), there is no difference between face-to-face education when educational technologies and distance education are configured correctly. The focus in education should be to ensure the quality of educational delivery and content.

\section{Conclusion}

The global pandemic caused by COVID-19 has caused serious changes in both education and exam practices in the last period of the 2019-2020 academic years, and distance/online education has become paramount. It is important to identify deficiencies in order to develop and improve this education method, which has transitioned rapidly due to the sudden start of the process. The faculty of medicine was more affected by this process due to the necessity of practical education. In the transition to distance education, there are difficulties in the measurement-evaluation processes rather than the presentation of the content with educational technologies. Distance education can provide both limitations and opportunities for clinical neurology education. While such applications are included in the scope of education, both the content compliance and the characteristics of the students should be considered. Transferring traditional processes to distance education without making the necessary arrangements in assessment and evaluation practices creates great limitations. 


\section{Ethics}

Ethics Committee Approval: Clinical Research Ethics Committee of the University of Canakkale Onsekiz Mart University and the Dean of the Faculty of Medicine (decision no: 2020-14, date: 09.12.2020).

Informed Consent:All participants were given their consent before filling out the online questionnaire.

Peer-review: Externally peer-reviewed.

\section{Authorship Contributions}

Concept: Ö.O., E.M.Ş., Design: Ö.O., E.M.Ş., Data Collection or Processing: Ö.O., E.M.Ş., Analysis or Interpretation: Ö.O., E.M.Ş., Literature Search: Ö.O., E.M.Ş., Writing: Ö.O., E.M.Ş.

Conflict of Interest: No conflict of interest was declared by the authors.

Financial Disclosure: The authors declared that this study received no financial support.

\section{References}

1. World Health Organization (WHO). Q\&As on COVID-19 and related health topics. Available from: https://www.who. int/emergencies/diseases/ novel-coronavirus-2019/question-andanswers-hub. Accessed date: 19.01.2021.

2. Bozkurt A, Sharma RC. Emergency remote teaching in a time of global crisis due to CoronaVirus pandemic. Asian Journal of Distance Education 2020;15:i-vi.

3. UNESCO. School closures caused by Coronavirus (Covid-19). Available from: https://en.unesco.org/covid19/educationresponse. Accessed date: 19.01.2021.

4. Dehghanbanadaki H, Seif F, Vahidi Y, et al. Bibliometric analysis of global scientific research on Coronavirus (COVID-19). Med J Islam Repub Iran 2020;34:354-362.

5. Schon F, Hart P, Fernandez C. Is clinical neurology really sodifficult? J Neurol Neurosurg Psychiatry 2002;72:557-559.

6. Gelb DJ, Gunderson CH, Henry KA, et al. The neurology clerkship core curriculum. Neurology 2002;58:849-852.

7. Flanagan E, Walsh C, Tubridy N. 'Neurophobia'--attitudes of medical students and doctors in Ireland to neurological teaching. Eur J Neurol 2007;14:1109-1112.

8. TEPDAD. Akredite Eğitim Programlarının Güncel Listesi. Available from: http://tepdad.org.tr/akredite-egitim-programlarinin-guncel-listesi. Accessed date: 19.01.2020

9. Zimmerman J. Coronavirus and the Great Online-Learning Experiment The Chronicle of Higher Education. Available from: https://www.chronicle. com/article/CoronavirustheGreat/248216. Accessed date: 19.01.2020.
10. Karadağ E, Yücel C. Distance Education at Universities during the Novel Coronavirus Pandemic: An Analysis of Undergraduate Students' Perceptions. Journal of Higher Education 2020;10:181-192.

11. Tokuc B, Varol G. Medical Education in Turkey in Time of COVID-19. Balkan Med J 2020;37:180-181.

12. Bozkurt A. Educational technology research patterns in the realm of the digital knowledge age. Journal of Interactive Media in Education 2020;18.

13. Richardson JC, Maeda Y, Lv J, Caskurlu S. Social presence in relation to students' satisfaction and learning in the online environment: A metaanalysis. Computers in Human Behavior 2017;71:402-417.

14. Reime MH, Harris A, Aksnes J, Mikkelsen J. The most successful method in teaching nursing students infection control-Elearning or lecture? Nurse Educ Today 2008;28:798-806.

15. Jang KS, Hwang SY, Park SJ, Kim YM, Kim MJ. Effects of a Webbased teaching method on undergraduate nursing students' learning of electrocardiography. J Nurs Educ 2005;44:35-39.

16. Prati C, Pelliccioni GA, Sambri V, Chersoni S, Gandolfi MG. COVID-19: its impact on dental schools in Italy, clinical problems in endodontic therapy and general considerations. Int Endod J 2020;53:723-725.

17. Budzinski JW, Farrell B, Pluye P, et al. An online knowledge resource and questionnaires as a continuing pharmacy education tool to document reflective learning. Am J Pharm Educ 2012;76:82.

18. Park SW, Jang HW, Choe YH, et al. Avoiding student infection during a Middle East respiratory syndrome (MERS) outbreak: a single medical school experience. Korean J Med Educ 2016;28:209-217.

19. Sinopidis X, Gkentzi D, Karatza A, Fouzas S. Considerations on Medical Education During the Coronavirus Disease 2019 Pandemic and Beyond. Balkan Med J 2021;38:61.

20. Bozkurt A. Koronavirüs (Covid-19) pandemi süreci ve pandemi sonrasi dünyada eğitime yönelik değerlendirmeler: Yeni normal ve yeni eğitim paradigması. AUAd 2020;6:112-142.

21. Sabzwari S. Rethinking Assessment in Medical Education in the time of COVID-19. Med Ed Publish 2020;9:80.

22. Boursicot K, Kemp S, Ong TH, et al. Conducting a high-stakes OSCE in a COVID-19 environment. Med Ed Publish 2020;9:54.

23. Hargreaves E. The Validity of Collaborative Assessment for Learning. Assessment in Education: Principles, Policy \& Practice 2007;14:185-199.

24. Akimov A, Malin M. When old becomes new: a case study of oral examination as an online assessment tool. Assessment \& Evaluation in Higher Education 2020;45:1205-1221.

25. Rowe N. Cheating in Online Student Assessment: Beyond Plagiarism. OJDLA 2004;7:1-10.

26. Russel TL. The No significant difference phenomenon as reported in 355 research reports, summaries and papers. USA: North Carolina State University, 1999. 